\title{
ELECTROLYTES CHANGES IN MALE RATS DEPRIVED OF FEED AND WATER
}

\author{
B.S. OKEDIRAN ${ }^{1}$; S.A. AMID ${ }^{2}$; K.Y. SULEIMAN ${ }^{1}$; A.S. ADAH ${ }^{1}$; F. SANUSI ${ }^{1}$ \\ AND F.H. OLAIFA ${ }^{1}$ \\ ${ }^{1}$ Department of Veterinary Physiology and Biochemistry, Faculty of Veterinary Medicine, University \\ of Ilorin, Ilorin, Nigeria \\ ${ }^{2}$ Department of Veterinary Surgery and Radiology, Faculty of Veterinary Medicine, University \\ of Ilorin, Ilorin, Nigeria.
}

Received: 20 May 2021; Accepted: 20 June 2021

\begin{abstract}
ABATRACT
Electrolytes are of great importance in cell metabolism because they are important cofactors or coenzymes needed for normal functioning of cells. The disturbances of these electrolytes result in changes of cell $\mathrm{pH}$ and acid base balance. In order to determine the electrolytes changes following feed and water deprivation in male rats, a total of ten $(n=10)$ male albino rats weighing $(152 \pm 3.50) \mathrm{g}$ housed in metallic cage were used for this study. The rats were deprived of feed and water consecutively for six days. On the third and sixth days blood samples were obtained for electrolytes studies in the plasma and in the erythrocytes. There were significant increases $(\mathrm{P}<0.05)$ in plasma sodium, potassium, calcium, magnesium, chloride and bicarbonate concentrations in comparison to the basal parameters while significant decreases $(\mathrm{P}<0.05)$ in erythrocytes sodium, potassium, calcium, magnesium, chloride and bicarbonate concentrations in comparison to the basal parameters were observed. It can be concluded that deprivation of male albino rats of food and water for six consecutive days resulted in perturbation, stress, dehydration and redistribution of electrolytes in various compartments of the cell.
\end{abstract}

Key words: Electrolytes, erythrocytes, plasma, rats

\section{INTRODUCTION}

Deprivation of food and water are common features of biomedical and behavioral research as well as a method of standardization of animals for experimental and assay procedures. Feed and water are very essential for well-being of the animals because it contains carbohydrates, proteins, lipids, vitamins and minerals in

Corresponding author: B.S. Okediran

E-mail address: okediranbabatunde@gmail.com

Present address: Department of Veterinary Physiology and Biochemistry, Faculty of Veterinary Medicine, University of Ilorin, Ilorin, Nigeria proportionate amounts for sustainability of the animals (Okediran et al., 2021; Armstrong et al., 1980). When animals are deprived of feed and water, the cellular biochemistry and internal environment are altered such that the biomolecules metabolism are deranged to cope with the stress experienced as a result of the deprivation of feed and water (Ottenweller, 1992). It was reported that corticosteroids such as cortisol are elevated as a result of stress experienced due to feed and water deprivation (Ottenweller, 1992). 
Haematological and some biochemical changes were reported when male rats were deprived of feed and water for six consecutive days. The changes ranges from haemoconcentration, dehydration with relative polycythaemia (Okediran et al., 2021).

Other biochemical changes observed were stress induced increased activities of liver enzymes such as aspartate aminotransferase and alanine aminotransferase (Lin et al., 2005; Okediran et al., 2021), increase lipid metabolism as a result of activation of hormone sensitive lipase (Mahboob et al., 1999), rapid mobilization and hydrolysis of triglyceride in adipose tissue, causing a rise in plasma free fatty acid concentration (Moitra et al., 1998; Kersten et al., 1999) to generate energy since glucose is in short supply. Similarly, protein metabolism was perturbed due to dehydration with evidence of azotaemia, hyperproteinaemia and hyperalbuminaemia (Keenan et al., 1994).

Haematological and biochemical changes were reported in male rats subjected to feed and water deprivation for six consecutive days (Okediran $e t$ al., 2021), however electrolytes play significant role in maintaining various biochemical activities within the cell either as a cofactor or coenzymes in biochemical pathways. They equally contribute in maintaining the conformation of enzymes most especially membrane bound enzymes. This study is to unravel some of the changes that might affect the electrolytes when male rats were deprived of feed and water for six consecutive days.

\section{MATERIALS AND METHODS}

\section{Animal ethics}

All experimental protocols carried out on the animals were in accordance with the international accepted principles for laboratory animal use and were approved by the Ethics Committee (UIL/FVERC/001/2020) on Laboratory animal use of the Faculty of Veterinary Medicine, University of Ilorin, Nigeria.

\section{Experimental animals}

A total of ten $(n=10)$ male albino rats were used for this investigation. The average weight of the rats was $(152 \pm 3.50) \mathrm{g}$. These rats were housed in metallic cage under standard room temperature $\left(20.0{ }^{\circ} \mathrm{C}\right)$ and pressure $(760 \mathrm{mmHg})$. They were provided with laboratory animal feed (Fat/oil 6\%, crude fibre $5 \%$, calcium $1 \%$, Available phosphorus $0.4 \%$, Lysine $0.85 \%$, Methionine $0.35 \%$, Salt $0.3 \%$, Crude protein $18 \%$, Metabolizeable Energy $2900 \quad \mathrm{Kcal} / \mathrm{kg}$ manufactured by TOPFEEDS® (Lagos, Nigeria) and water provided. Experimental animals were acclimatized to the room temperature $\left(20.0^{\circ} \mathrm{c}\right)$ and pressure $(760 \mathrm{mmHg})$ before the start of the experiment.

\section{Plasma preparation}

The tail of the restrained rat was cleansed with a ball of cotton wool soaked in methylated spirit. A little vaseline was then smeared on the tail to reduce friction while massaging to redness. Gentle massage towards the tip of the tail continued until the tip became red as a sign of blood accumulation. The red tip of the tail was then slightly and carefully incised with new and sterilized blade and further massaged gently as the blood trickled into immobilized sample tubes containing lithium heparin. Cotton wool soaked in methylated spirit was again used to cleanse the incised area of the tail. The blood was centrifuged at $4000 \mathrm{rpm}$ for 10 minutes to separate the plasma from the cellular components. The plasma were then decanted and stored in Eppendorf tubes for further analyses as described by Schalm et al. (1975).

\section{Erythrocytes storage}

The erythrocytes obtained after decanting the plasma were suspended in $20 \mathrm{mM}$ Tris $\mathrm{pH} 7.6$ buffer. The erythrocytes were washed in the buffer until free of plasma for the determination of some electrolytes in the erythrocytes. 


\section{Electrolytes determination}

Some basal electrolytes concentrations were determined in the plasma and erythrocytes before the animals were deprived of feed and water. The animals were deprived of feed and water for six consecutive days. Blood samples were collected on the third and sixth day for electrolytes concentration determination in the plasma and in the erythrocytes.

Sodium, potassium, calcium, magnesium chloride and bicarbonate concentrations were determined spectrophotometrically as outlined in Randox biochemical kit described by Tietz et al. (1986).

\section{Statistical analysis}

Results were expressed as mean \pm standard error of mean. Analysis of the data was done using one-way analysis of variance followed by the Duncan multiple range test. A $\mathrm{P}<0.05$ was considered significant. All analyses were done using Graph Pad Prism Version 5.

\section{RESULTS}

Table 1 shows the plasma electrolytes concentrations of male rats deprived of feed and water for six consecutive days. There were significant increases $(\mathrm{P}<0.05)$ in plasma sodium, potassium, calcium, magnesium, chloride and bicarbonate concentrations on the third and sixth days post feed and water deprivation in comparison to the basal parameters. Comparison between the third and the sixth day post feed and water deprivation showed that there were further increases of these parameters, which were significant only for potassium, chloride and bicarbonate

Table 1: Shows the plasma electrolytes concentrations of rats deprived of feed and water for six consecutive days

\begin{tabular}{cccc}
\hline Parameters & Basal & $\begin{array}{c}\text { Three days post feed } \\
\text { and water deprivation }\end{array}$ & $\begin{array}{c}\text { Six days post feed and water } \\
\text { deprivation }\end{array}$ \\
\hline Sodium $(\mathrm{mEq} / \mathrm{L})$ & $75.95 \pm 0.40 \mathrm{a}$ & $80.20 \pm 0.35 \mathrm{~b}$ & $82.34 \pm 0.30 \mathrm{~b}$ \\
\hline Potassium $(\mathrm{mEq} / \mathrm{L})$ & $12.15 \pm 0.33 \mathrm{a}$ & $15.62 \pm 0.21 \mathrm{~b}$ & $16.18 \pm 0.10 \mathrm{c}$ \\
\hline Calcium $(\mathrm{mEq} / \mathrm{L})$ & $1.25 \pm 0.02 \mathrm{a}$ & $1.36 \pm 0.04 \mathrm{~b}$ & $1.46 \pm 0.10 \mathrm{~b}$ \\
\hline Magnesium $(\mathrm{mEq} / \mathrm{L})$ & $0.55 \pm 0.04 \mathrm{a}$ & $0.76 \pm 0.02 \mathrm{~b}$ & $0.74 \pm 0.12 \mathrm{~b}$ \\
\hline Chloride $(\mathrm{mEq} / \mathrm{L})$ & $82.03 \pm 0.31 \mathrm{a}$ & $87.24 \pm 0.40 \mathrm{~b}$ & $89.10 \pm 0.35 \mathrm{c}$ \\
\hline Bicarbonate $(\mathrm{mEq} / \mathrm{L})$ & $63.67 \pm 0.30 \mathrm{a}$ & $68.17 \pm 0.35 \mathrm{~b}$ & $70.23 \pm 0.25 \mathrm{c}$ \\
\hline
\end{tabular}

Values within the same rows with different superscripts $(\mathrm{a}, \mathrm{b}, \mathrm{c})$ are significantly different at $\mathrm{P}<0.05$.

Table 2 shows the erythrocytes electrolytes concentrations of male rats deprived of feed and water for six consecutive days. There were significant decreases $(\mathrm{P}<0.05)$ in erythrocytes sodium, potassium, calcium, magnesium, chloride and bicarbonate concentrations on the third and sixth day post feed and water deprivation in comparison to the basal parameters. Comparison between the third and sixth day post feed and water showed that there were further decreases in these parameters which were significant only for sodium and potassium. 
Table 2: Shows the erythrocytes electrolytes concentrations of rats deprived of feed and water for six consecutive days

\begin{tabular}{cccc}
\hline Parameters & Basal & $\begin{array}{c}\text { Three days post feed and } \\
\text { water deprivation }\end{array}$ & $\begin{array}{c}\text { Six days post feed and } \\
\text { water deprivation }\end{array}$ \\
\hline Sodium $(\mathrm{mEq} / \mathrm{L})$ & $13.25 \pm 1.03 \mathrm{a}$ & $10.20 \pm 0.35 \mathrm{~b}$ & $8.04 \pm 0.10 \mathrm{c}$ \\
\hline Potassium $(\mathrm{mEq} / \mathrm{L})$ & $26.15 \pm 1.33 \mathrm{a}$ & $12.12 \pm 0.11 \mathrm{~b}$ & $10.18 \pm 0.14 \mathrm{c}$ \\
\hline Calcium $(\mathrm{mEq} / \mathrm{L})$ & $10.12 \pm 1.02 \mathrm{a}$ & $8.16 \pm 0.14 \mathrm{~b}$ & $7.26 \pm 0.10 \mathrm{~b}$ \\
\hline Magnesium $(\mathrm{mEq} / \mathrm{L})$ & $9.15 \pm 1.04 \mathrm{a}$ & $7.06 \pm 0.02 \mathrm{~b}$ & $6.14 \pm 0.11 \mathrm{~b}$ \\
\hline Chloride $(\mathrm{mEq} / \mathrm{L})$ & $11.03 \pm 1.01 \mathrm{a}$ & $8.22 \pm 0.20 \mathrm{~b}$ & $7.10 \pm 0.13 \mathrm{~b}$ \\
\hline Bicarbonate $(\mathrm{mEq} / \mathrm{L})$ & $14.27 \pm 1.30 \mathrm{a}$ & $12.11 \pm 0.15 \mathrm{~b}$ & $11.13 \pm 0.20 \mathrm{~b}$ \\
\hline
\end{tabular}

Values within the same rows with different superscripts $(\mathrm{a}, \mathrm{b}, \mathrm{c})$ are significantly different at $\mathrm{P}<0.05$.

\section{DISCUSSION}

Water deprivation and restriction are common features of biomedical and behavioral research. Water deprivation studies are designed to produce a behavioral or physiologic effect by withholding water from animals for various periods of time. Most studies use the water restriction paradigm to produce a consistent state of physiologic need that can be used to study fluid homeostasis or to induce a motivational stimulus to perform a behavioral task (Homma $e t$ al., 2002). The chronic nature of this type of study requires close monitoring of the animals' overall health and behavior throughout the experiment (Rowland, 2007; Toth and Gardiner, 2000).

Electrolytes play a significant role in several body processes, such as controlling fluid levels, acid- base balance $(\mathrm{pH})$, nerve conduction, blood clotting process, muscle contraction as well as a cofactor or coenzymes (Hasona and Elasbali, 2016). Fluid and electrolytes homeostasis is usually maintained within narrow limits by the kidney (Roberts, 2005), and therefore it must be kept at a level that is suitable for normal biochemical and physiological functions (Kaneko et al., 2008). Therefore, imbalance in serum electrolytes is an important sensitive indicator of feed and water deprivation as it causes disturbance in general health status of animals (Ergonui et al., 2012; Chezhian et al., 2011; Shaista et al., 2010).
In this study, a significant increase was observed in the electrolytes measured on the third day with further increase on the sixth day. This is attributed to moderate dehydration experienced by these animals. There was haemoconcentration hence the body starts to withdraw fluid from the interstitial fluid into the circulation within two to three days to maintain blood volume. There is minor dilution of blood within these three days. Within the next three days there is further haemoconcentration which stimulate the kidney to reabsorb water to maintain the blood volume. The significant decrease in chloride and bicarbonate concentrations in the erythrocyte and their increase in the plasma observed in this study could lead to disturbance in acid-base balance (Abubakar and Sule, 2010). Severe dehydration was equally reported by other workers producing altered electrolytes metabolism resulting in muscle weakness and cardiac arrhythmias that lead to heart failure (Abubakar and Sule, 2010; Kruetler, 1980). This imbalance might affect their homeostatic distribution and physiological roles, which is maintained through coordinated interaction of the intestine, the site of net absorbtion; and the kidney, the site of net excretion (Favus et al., 2006).

Abnormal concentration of sodium and or potassium in the blood can affect the osmotic pressure of the body fluid which is related to blood pressure (Cheesbrough, 2002; Healy, 1995). Sodium attracts water and so when sodium level rises in the blood, the body retains 
water, thereby decreasing sodium concentration. Blood pressure which depends in part on blood volume increases as retained water rises (Kruetler, 1980).

One major side effect of feed and water deprivation of rats is the mobilization and redistribution of the electrolytes within different compartments of the cells to achieve homeostasis. We observed mobilization of electrolytes leaving the intracellular fluid of the erythrocytes into the extracellular fluid i.e the plasma. This is attributed to the stress of dehydration on the erythrocytes causing alteration of metabolism of these electrolytes to leak into extracellular fluid as a result of altered configuration of membrane bound enzymes controlling movement of electrolytes in and outside the cell (Okediran et al., 2021). The basis for life is the ability of the cell to maintain ion gradient across biological membranes, the molecular basis of feed and water deprivation on electrolytes have not been described. Sodium, potassium, calcium and magnesium has a sensing receptors they bind to, which are located on the membrane (Handlogten et al., 2000; Brown et al., 1998). In normal red cell metabolism, intracellular sodium, potassium, calcium and magnesium concentrations were controlled by reverse binding to specific electrolytes binding proteins, whereas the calcium and magnesium, sodium and potassium flux across the external membrane are regulated by $\mathrm{Ca}^{2+}-\mathrm{Mg}^{2+}$-ATPase and $\mathrm{Na}^{+}-\mathrm{K}^{+}$-ATPase (Katz,1985). Dehydration induced stress may therefore interfere with these electrolytes homeostasis by promoting their influx into or inhibiting their efflux from the cytoplasm. They also may diminish the efflux of these ions by inhibiting the ion pumps or depleting the ion pumps of their driving forces (Gregus and Klaassen, 2003; Timbrell, 2000). The increased concentration of electrolytes in the plasma and subsequent reduction in the erythrocytes is an indication that feed and water deprivation induced stress causes efflux of these electrolytes into the plasma but inhibiting the influx into the intracellular erythrocytes. Alterations in chemical and physical characteristics of erythrocytes membranes have been reported (Valentino et al., 1982; Karai et al., 1981; Quintanar-Escorza et al., 2007). The attendant consequences of these alterations include decreased fluidity and increased osmotic fragility of the cell erythrocyte membrane (Valentino et al., 1982; Karai et al., 1981; Quintanar-Escorza et al., 2007). The consequences of these is imbalance in the electrolyte distribution due to stress caused by feed and water deprivation. Chronic water and feed deprivation is generally not associated with marked adrenal activation however, glucocorticoid elevations during dehydration due to stress might cause diuretic effects that would counter fluid conservation mechanisms (Heiderstadt, 2000).

In conclusion feed and water deprivation should not be encouraged for a long time because it induces stress, haemoconcentration and dehydration leading to massive redistribution and alteration of electrolytes in various compartments of the body thereby disturbing acid base balance of the animals.

\section{REFERENCES}

Abernethy, M.H. and Fowler, R.T. (1982): Micellar improvement of the calmagite compleximetric measurement of magnesium in plasma. Clinical Chemistry 28(3): 520-22.

Abubakar, S.M. and Sule, M.S. (2010): Effect of oral administration of aqueous extract of Cassia occidentalis L. seeds on serum electrolytes concentration in rats. Bayero Journal of Pure and Applied Sciences 3 (1): 183-187.

Armstrong, S.; Grahame, $C$. and Singer, $G$. (1980): Food and water deprivation: changes in rat feeding, drinking, activity, and body weight. Neurosciences and Biobehavioural Review 4: 377-402 
Brown, E.M.; Pollak, M. and Hebert, S.C. (1998): The extracellular calcium sensing receptor: it role in health and disease. Annual Review of Medicine 49: 15-20

Cheesbrough, M. (2002): District Laboratory Practice in Tropical Countries- Part 1. Cambridge University Press, Cambridge, U.K. 229-333.

Chezhian, A.; Kabilan, N.; Suresh, K. and Senthamil, S. (2011): Influence of different calcium levels and low $\mathrm{pH}$ of water on the plasma electrolytes regulation of a fresh water teleost fish cyprinus carpio var, communies, (Linnaeus, 1958). Current Research Journal of Biological Science 3 (2): 147-154.

Ergonui, M.B.; Atasagun, S. and Kocaturk, K. (2012): Alterations in the haematological and biochemical parameters and plasma ion concentrations of common carp, (Cyprinus carpio L, 1758) after short term exposure to sub-lethal concentrations of Lead. Kafkas, kafkas University Veteriner Fakultesi Dergisi, 18(2): 297-302

Favus, M.J.; Bushinsky, D.A. and Lemann-jr, J. (2006): Regulation of Calcium, Magnesium and Phosphate Metabolism. American Society for Bone and Mineral Research, Washington DC, US, PP. 76-83

Gregus, Z. and Klassen, C.D. (2003): Mechanism of toxicity. In: Klassen, C.D., Watkins III, J.B. (Eds), Casarett and Doull's Essentials of Toxicology, McGrawHill, New York, pp.21-45

Handlogten, M.E.; Shiraishi, N.; Awata, H.; Huang, C. and Miller, R.T. (2000): Extracellular $\mathrm{Ca}^{2+}$-sensing receptor is a promiscuous divalent cation sensor that responds to lead. American Journal of Renal Physiology 279: F1083-F1091.

Healy, T. (1995): Electrolytes-Their role and management. African Health 9-11.

Heiderstadt, K.M.; McLaughlin, R.M.; Wright, D.C.; Walker, S.E. and Gomez-Sanchez. C.E. (2000): The effect of chronic food and water restriction on open-field behavior and serum corticosterone levels in rats. Laboratory Animals 34: 20-26.

Hasona, A. and Elasbali, A. (2016): Evaluation of electrolytes imbalance and dyslipidaemia in diabetic patients. Medical Science 4 (7): $1-4$

Homma, S.; Takeda, S.; Kusano, E.; Matsuo, T.; Simizu, T.; Nakamura, M.; Oohara, T.; Makino, S. and Assano, Y. (2002): Impaired urinary concentrating ability in genetically polyuric mice. Nephron 92: 889-897.

Kaneko, J.J.; Harvey, J.W. and Bruss, M.L. (2008): Clinical Biochemistry of Domestic Animals, Sixth edition, Academic, London, pp 117-138

Karai, I.; Fukumoto, K. and Horiguchi, S. (1981): Studies on osmotic fragility of red blood cells determined with a coil planet centrifuge for workers occupationally exposed to lead. International Archive of Occupational and Environmental Health 48: 273-281.

Keenan, K.P.; Laroque, P. and Dixit, R. (1998): Need for dietary control by caloric restriction in rodent toxicology and carcinogenicity studies. Journal of Toxicology and Environmental Health. Critical Review 2: 135-148.

Kersten, S.; Seydoux, J.; Peters, J.M.; Gonzalez, F.J.; Desvergne, B. and Wrahli, W. (1999): Peroxisome proliferator activated receptor alpha mediates the adaptive response to fasting. Journal of Clinical Investigation 103: 1489-1498.

Kruetler, P.A. (1980): Nutrition in perspective. Prentice-Hall Inc., London. Pp: 327-336.

Lin, X.; Yue, P.; Chen, Z. and Schonfeld, G. (2005): Hepatic triglyceride contents are genetically determined in mice: results of a strain survey. American Journal of Physiology 288: G1179-G1189.

Mahboob, S.; Sattarivand, R.; Nouri, M. and Arefhosseini, S. (1999): Effect of Ramadan fasting on serum lipids profiles in normal 
and hyperlipidemic subjects. Saudi Medical Journal 20: 947-950.

Moitra, J.; Mason, M.M. and Olive, M. (1998): Life without white fat: a transgenic mouse. Genes Development 12: 3168-3181.

Okediran, B.S.; Amid, S.A.; Sanusi, F. and Oladesu, K.O. (2021): Haematological and biochemical changes associated with male rats deprived of feed and water. Ceylon Journal of Science 50(1): 11-16.

Ottenweller, J.E.; Servatius, R.; Tapp, W.; Drastal, S.; Bergen, M. and Natelson, $B$. (1992): A chronic stress state in rats: effects of repeated stress on basal corticosterone and behavior. Physiological Behaviour 51: 289-298

Quintanar-Escorza, M.A.; Gonzalez-Martinez, M.T.; Navarro, L.; Maldonado, M.; Arevalo, B. and Calderon-Salinas, J.V. (2007): Intracellular free calcium concentration and calcium transport in human erythrocytes of lead exposed workers. Toxicological and Applied Pharmacology 220: 1-8.

Roberts, K.E. (2005): Pediatric Fluid and Electrolytes Balance: Critical Care Case Studies. Critical Care Nursing Clinics of North America 17(4): 361-471.

Rowland, N.E. (2007): Food or fluid restriction in common laboratory animals: balancing welfare considerations with scientific inquiry. Companion Medicine 57: 149-160.

Shaista, N.; Saeed, A.N.; Yasar, S. and Armit, P. (2010): Determination of heavy metals in fresh water fish species of the river ravi, Pakistan compared to farmed fish varieties.
Environmental Monitoring and Assessment 167 (14): 461-471.

Schalm, D.W.; Jain, N.C. and Carrot, E.J. (1975): Veterinary Haematology. 3rd edn., Lea and Febiger, Philadelphia, ISBN-13: 978-0812104707 Pp: 807.

Schmidt-Gayk, H.; Blind, E. and Roth, H.J. (1953): Hormones and markers of bone metabolism. Measurement and interpretation, 2nd (Edn.), Clinical Laboratory Publications, Heidelberg. Pp: 20-29

Teitz, N.W.; Pruden, E.L. and SiggaardAndersen, O. (1986): Electrolytes, Blood gases and Acid-Base Balance. In: Textbook of Clinical Chemistry, N.W. Tietz, Editor, Saunders, Philadelphia. Pp: 1188.

Terri, A.E. and Sesin, P.G. (1958): Quantitative determination of serum potassium by nephelometric method. American Journal of Clinical Pathology 29: 86-88.

Timbrell, J. (2000): Principle of Biochemical Toxicology, third ed. Taylor and Francis, London. Pp: 175-258

Toth, L. and Gardiner, T. (2000): Food and water restriction protocols: physiological and behavioral considerations. Contemporary Tropical Laboratory Animal Science 39: 917.

Trinder, P. (1951): Quantitive determination of serum sodium by colorimetric method. Anal 76: 596-598.

Valentino, M.; Fiorini, R.M. and Curatola, M. (1982): Changes of membrane fluidity in erythrocytes of lead exposed workers. International Archive of Occupational and Environmental Health 51:105-112. 